\title{
Theopapuamide: a Cyclic Depsipeptide from a Papua New Guinea Lithistid Sponge Theonella swinhoei
}

\author{
Anokha S. Ratnayake ${ }^{\dagger}$, Tim S. Bugni ${ }^{\dagger}$, Xidong Feng $^{\ddagger}$, Mary Kay Harper ${ }^{\dagger}$, Jack J. Skalicky§, \\ Kaleem A. Mohammed ${ }^{\dagger}$, Cynthia D. Andjelic ${ }^{\perp}$, Louis R. Barrows ${ }^{\perp}$, and Chris M. Ireland ${ }^{\dagger},{ }^{\star}$ \\ Department of Medicinal Chemistry, Department of Biochemistry and Department of Pharmacology \\ and Toxicology, University of Utah, Salt Lake City, Utah 84112 and Wyeth Research, 401 North \\ Middletown Road, Pearl River, New York 10965
}

\begin{abstract}
Theopapuamide (1), a new cytotoxic peptide has been isolated from the lithistid sponge Theonella swinhoei from Papua New Guinea. The structure was established by analysis of NMR, mass spectrometry and chemical methods. The undecapeptide (1) contains several unusual amino acid residues, of which the occurrence of $\beta$-methoxyasparagine and 4-amino-5-methyl-2,3,5-trihydroxyhexanoic acid (Amtha) is unprecedented in natural peptides. Compound $\mathbf{1}$ also contains a amide linked fatty acid moiety, 3-hydroxy-2,4,6-trimethyl-octanoic acid (Htoa). Theopapuamide (1) was cytotoxic against CEM-TART and HCT-116 cell lines with $\mathrm{EC}_{50}$ values of $0.5 \mu \mathrm{M}$ and $0.9 \mu \mathrm{M}$ respectively.
\end{abstract}

Marine sponges have proven to be a significant source of biologically active cyclic peptides and depsipeptides. ${ }^{1}$ Among these sponge depsipeptides, callipeltin A (from New Caledonian sponge Callipelta sp.), ${ }^{2}$ neamphamide A (from a Papua New Guinea sponge Neamphius huxleyi) ${ }^{3}$ and Papuamides A-B (from Papua New Guinea sponges Theonella mirabilis and Theonella swinhoei $)^{4}$ are well known for their potent HIV-inhibitory activity and their structurally unique features incorporating several modified amino acid residues. For instance, the atypical amino acid residues 3,4-dimethyl-L-glutamine and $\beta$-methoxytyrosine are common to all of the above mentioned marine depsipeptides but to date have not been described elsewhere. The rarity of these atypical amino acid residues has inspired their chemical synthesis. ${ }^{5}$ The structural diversity found among lithistid sponge metabolites (genus Theonella and Callipelta) has been attributed to symbiotic microorganisms. ${ }^{1}$

As part of our continuing studies on Theonella swinhoei from Papua New Guinea, ${ }^{6}$ the aqueous $\mathrm{CH}_{3} \mathrm{CN}$ extract of the sponge was analyzed and proved active in an in vitro anti-HIV assay. Fractionation of the active extract resulted in the isolation of a new cyclic depsipeptide, theopapuamide (1). This paper describes the isolation, structure elucidation, and stereochemical analysis of theopapuamide (1).

The crude aqueous $\mathrm{CH}_{3} \mathrm{CN}$ extract of $T$. swinhoei (family Theonellidae) was concentrated under vacuum and fractionated by $\mathrm{C} 18$ flash column chromatography. Further purification on Diaion HP-20 resin followed by CN-HPLC afforded the new cyclic undecapeptide,

\footnotetext{
*To whom correspondence should be addressed. Tel: (801) 581-8305. Fax: (801) 585-6208. E-mail: cireland@ pharm.utah.edu.

$\dagger$ Department of Medicinal Chemistry

Wyeth Research, Pearl River, New York

$\S$ Department of Biochemistry

$\perp_{\text {Department of Pharmacology and Toxicology }}$
} 
theopapuamide $\left(1,15.8 \mathrm{mg}, 3.95 \times 10^{-3} \%\right.$ yield wet wt) as an off-white amorphous solid $\left([\alpha]^{25} \mathrm{D}-3.0, c 0.86, \mathrm{MeOH}\right)$.

For compound 1 , a molecular formula of $\mathrm{C}_{69} \mathrm{H}_{123} \mathrm{~N}_{17} \mathrm{O}_{23}$ was established based on the divalent molecular ion $[\mathrm{M}+2 \mathrm{H}]^{2+}$ observed at $m / z 779.9563$ by HRESI-FTMS. The protonated molecular ion at $m / z 1558.9053[\mathrm{M}+\mathrm{H}]^{+}$in the HRESI-FTMS was in agreement with a molecular weight of $1557.8980 \mathrm{Da}(\Delta=-0.2 \mathrm{mmu})$ for the neutral compound (1). The molecular formula suggested seventeen units of unsaturation. Subsequent examination of 1Dspectra of 1 reflected characteristic features of a peptide, such as an abundance of exchangeable $\mathrm{N}-\mathrm{H}$ protons $\left(\delta_{\mathrm{H}} 6.55-9.05\right)$ and carbonyl signals $\left(\delta_{\mathrm{C}} 169.9-179.6\right)$ in the ${ }^{1} \mathrm{H}$ and ${ }^{13} \mathrm{C}$ NMR spectra, respectively. However, the interpretation of NMR spectra of $\mathbf{1}$ was hampered by the existence of multiple conformations in several of the common NMR solvents $\left(\mathrm{MeOH}-d_{4}\right.$, $\mathrm{CD}_{3} \mathrm{CN}$ :DMSO- $d_{6}$ and DMSO- $d_{6}$ ). Attempts to improve resolution by employing acetone$d_{6}$ and DMF- $d_{7}$ as solvents failed due to poor solubility of $\mathbf{1}$. Moreover, efforts to achieve a favorable conformational ratio by addition of $\mathrm{LiCl}^{7}\left(0.5-4\right.$ equi., $\mathrm{CD}_{3} \mathrm{CN}$ :DMSO- $\left.d_{6}, 25^{\circ} \mathrm{C}\right)$ was also ineffective. Gratifyingly, one major conformation, with improved resolution, was observed using a mixture of $\mathrm{CD}_{3} \mathrm{CN}: \mathrm{H}_{2} \mathrm{O}(4: 1)$ at $25^{\circ} \mathrm{C}$.

The aliphatic nature of the peptide was supported by the absence of any $\mathrm{sp}^{2}$-hybridized carbon resonances in the region between $110-150 \mathrm{ppm}$, as well as localization of resonances in the upfield region of the ${ }^{13} \mathrm{C}$ NMR spectrum of $\mathbf{1}$. Due to the extensive overlap of aliphatic resonances in $\mathbf{1}$, the assembly of individual amino acid residues required combined analysis of ${ }^{1} \mathrm{H}-{ }^{1} \mathrm{H}-\mathrm{COSY}$, gHSQC, gHSQC-TOCSY, 1D-TOCSY and z-DIPSI-tocsy ${ }^{8}$ spectra. In conjunction with NMR analysis, the gross structure elucidation of $\mathbf{1}$ was guided by standard amino acid analysis, ${ }^{9}$ which revealed molar concentrations of $\sim 1: 2: 1$ for Asx, Thr and Leu respectively. The presence of two $\mathrm{N}$-methylated amino acid residues were suggested based on the characteristic ${ }^{1} \mathrm{H}$ and ${ }^{13} \mathrm{C}$ chemical shifts of the $\mathrm{N}$-methyl groups at $\delta_{\mathrm{H}} 2.81\left(\delta_{\mathrm{C}} 30.8\right)$ and $\delta_{\mathrm{H}} 2.88\left(\delta_{\mathrm{C}} 31.8\right)$. $\mathrm{HMBC}$ correlations were used to identify these $\mathrm{N}$-methylated amino acids as NMeLeu and NMeGln, respectively. Additionally, the presence of a methoxy-bearing amino acid residue was suggested by the characteristic ${ }^{1} \mathrm{H}$ and ${ }^{13} \mathrm{C}$ chemical shifts of the O-methyl group at $\delta_{\mathrm{H}} 3.34\left(\delta_{\mathrm{C}} 60.3\right)$. Based on HMBC correlations, the methoxy-bearing amino acid residue was identified as $\beta$-OMeAsn. An ester linked threonine residue was suggested from a typical $\sim 1.0$ ppm downfield shift of the $\beta$-hydroxymethine proton $\left(\delta_{\mathrm{H}} 5.55\right)$. A subsequent ${ }^{15} \mathrm{~N}-\mathrm{HSQC}$ experiment showed four pairs of signals for the primary amide protons of 3,4-diMeGln, Asn, $\beta$-OMeAsn and NMeGln residues. However, the ${ }^{1} \mathrm{H}-{ }^{15} \mathrm{~N}$-correlations for the primary amino protons of Orn and Dpr could not be observed under the given experimental conditions $\left[\mathrm{CD}_{3} \mathrm{CN}-\mathrm{H}_{2} \mathrm{O}(4: 1), 25^{\circ} \mathrm{C}\right]$.

The connectivity between amino acid residues was established based on careful analysis of HMBC, WATERGATE-NOESY and WATERGATE-ROESY ${ }^{10}$ spectra. Further inspection of HMBC data supported formation of an 8-residue ring moiety in $\mathbf{1}$ via an ester linkage between the C-3-hydroxyl group of $\mathrm{Thr}\left(\delta_{\mathrm{H}-3} 5.55\right)$ and the $\mathrm{C}$-1-carboxylic acid of NMeLeu $\left(\delta_{\mathrm{C}-1} 171.5\right)$. Additionally, a NOESY cross peak between $\mathrm{Thr}\left(\delta_{\mathrm{H}-3} 5.55\right)$ and NMeLeu $\left(\delta_{\mathrm{H}-2}\right.$ 5.07) was in agreement with such a macrocyclic ring formation. The constituents of the macrocycle, identified based on sequential $\alpha-\mathrm{NH} / \mathrm{NH}$ and $\alpha-\mathrm{NH} / \mathrm{NCH}_{3} \mathrm{NOESY}$ correlations, consisted of NMeLeu $\left(\delta_{\mathrm{CH} 3} 2.81\right)$, Asn $\left(\delta_{\mathrm{H}} 8.18\right), \beta-\mathrm{OMeAsn}\left(\delta_{\mathrm{H}} 6.69\right)$, NMeGln $\left(\delta_{\mathrm{CH} 3} 2.88\right)$, Leu $\left(\delta_{\mathrm{H}} 7.20\right)$, Orn $\left(\delta_{\mathrm{H}} 8.00\right)$, and two residues of Thr (Thr1 $\delta_{\mathrm{H}} 8.25$, Thr $\left.2 \delta_{\mathrm{H}} 8.89\right)$.

Furthermore, based on HMBC and NOESY data, the $\alpha-\mathrm{NH}\left(\delta_{\mathrm{H}} 8.89\right)$ of the ester linked Thr was attached to a 4-residue sequence of 3,4-diMeGln, 4-amino-5-methyl-2,3,5-trihydroxyhexanoic acid (Amtha), 2,3-diaminopropionic acid (Dpr) and 3-hydroxy-2,4,6-trimethyloctanoic acid (Htoa), forming the linear portion of the peptide. Of the component amino acid residues identified in undecapeptide 1,5 of the residues were also described in both callipeltin 
A and neamphamide A (3,4-diMeGln, Thr $(\times 2)$, Leu, and NMeGln). ${ }^{2,3}$ A Htoa dimer, bourgeanic acid has been isolated from several Ramalina sp. lichens. ${ }^{11}$

Concurrent attempts to sequence the peptide by Edman degradation ${ }^{12}$ were unsuccessful signifying a concealed or chemically modified N-terminus in 1. Additionally, theopapuamide (1) was resistant to digestion by a variety of proteases (trypsin, thermolysin and pepsin) ${ }^{13}$ likely due to collective effects of $\mathrm{N}$-methylated amino acid residues, peptide bonds involving $\mathrm{D}$-amino acids and the cyclic nature of $\mathbf{1}$. Initial attempts to clarify the amino acid sequence by MS/MS (ESI and MALDI) analysis of the intact cyclic depsipeptide (1) was not informative, and yielded random cleavage products. Subsequently, the ester linkage in theopapuamide (1) was subjected to base hydrolysis ( $1 \mathrm{~N} \mathrm{KOH}$, r.t., 2 h) to generate the acyclic peptide $2[\mathrm{~m} / \mathrm{z}$ $\left.1576.9(\mathrm{M}+\mathrm{H})^{+}\right]$. As anticipated, the acyclic peptide (2) was amenable to tandem MS approach. ${ }^{14}$ Accordingly, successful sequence analysis of $\mathbf{2}$ was carried out on the basis of fragment ion spectra generated by SORI-CID ESI-FTMS/MS (Figure 1).

The absolute configurations of the amino acid constituents of theopapuamide (1) were determined by acid hydrolysis of $\mathbf{1}\left(6 \mathrm{~N} \mathrm{HCl}, 110^{\circ} \mathrm{C}, 12 \mathrm{~h}\right)$, followed by chiral HPLC analysis of the hydrolysate, and RP-HPLC analysis of FDAA derivatives. ${ }^{15}$ By chiral HPLC [Chirex phase 3126(D), $i \mathrm{PrOH}-2 \mathrm{mM} \mathrm{CuSO}_{4}$ (5:95)], diagnostic peaks were observed for L-NMeLeu, D-Asp, L-Leu, L-NMeGlu, D-Orn and D-Dpr residues. The chrial HPLC analysis failed to give sufficient separation of the D/L-allo-Thr standards [D/L-allo-Thr (6.3)], but ruled out the presence of D/L-Thr in the hydrolysate of $\mathbf{1}$. Subsequently, acid hydrolysate of 1 was derivatized with FDAA and analyzed by RP-HPLC, which allowed for the assignment of Dconfiguration for the two allo-Thr residues. To facilitate configurational analysis of the remaining stereocenters in 1, X-ray crystallographic study was attempted. Unfortunately, under variety of conditions, theopapuamide (1) only yielded fine crystals that were unsuitable for Xray diffraction studies.

In summary, theopapuamide (1) was cytotoxic against CEM-TART and HCT-116 cell lines with $\mathrm{EC}_{50}$ values of $0.5 \mu \mathrm{M}$ and $0.9 \mu \mathrm{M}$ respectively. Theopapuamide (1) contains a high degree of D-amino acids and $\mathrm{N}$-methylated amino acids along with several other modified amino acid residues of non-ribosomal origin. Theopapuamide (1), neamphamide A and callipeltins share the same basic structural skeleton of a 7- or 8-residue ring moiety formed by cyclization through a $\beta$-hydroxyl group of a Thr residue and a poly-substituted side chain linked to the amino terminus of a 3,4-diMeGln residue. Since the 3,4-diMeGln residue is conserved in all of the above mentioned HIV-inibitory marine depsipeptides (callipeltin A, neamphamide A, and Papuamides AB), it has been postulated by Acevedo et al. $5 \mathrm{c}$ that the 3,4 -diMeGln residue may play a role in their biological activity. However, theopapuamide (1), which also carries the atypical 3,4-diMeGln residue, failed to show any appreciable HIV-activity. The major difference between theopapuamide (1) and related HIV-inhibitory peptides is the absence of a $\beta$-methoxytyrosine residue in $\mathbf{1}$. Therefore, this work indicates the potential significance of the $\beta$-methoxytyrosine residue for biological activity.

\section{Experimental Section}

\section{General Experimental Procedures}

Optical rotations were measured on a JASCO DIP-370 digital polarimeter. UV spectra were acquired in spectroscopy grade methanol using a Hewlett Packard 8452A diode array spectrophotometer. IR spectra were recorded on a JASCO FT/IR-420 spectrometer. NMR spectra were recorded on Varian INOVA spectrometers operating at 500/600 MHz and 125/150 $\mathrm{MHz}$, respectively. Chemical shifts are reported in ppm and were referenced to residual acetonitrile $\left(\delta_{\mathrm{C}} 118.69 ; \delta_{\mathrm{H}} 1.49\right)$ in $\mathrm{CD}_{3} \mathrm{CN}$ :water $(4: 1)$. Low-resolution mass spectra were obtained using a PE Sciex API III mass spectrometer operating in the ESI mode. High- 
resolution ESIMS analyses were performed on a Bruker (Billerica, MA) APEXII FTICR mass spectrometer equipped with an actively shielded 9.4 Tesla superconducting magnet (Magnex Scientific Ltd., UK), an external Bruker APOLLO ESI source, and a Synrad 50W CO2 CW laser. ${ }^{14}$ Nanoelectrospray was employed. Typically, a $5 \mu \mathrm{L}$ sample was loaded into the nanoelectrospray tip (New Objective, Woburn, MA) and a high voltage about $1000 \mathrm{~V}$ was applied between the nanoelectrospray tip and the capillary. Mass spectra were internally/ externally calibrated using HP tuning mix. In the FTMS/MS experiments, the precursor ions were isolated using correlated sweep and then dissociated using a Sustained Off-Resonance Irradiation with Collision Induced Dissociation (SORI-CID). Automated amino acid analysis was performed on a Hitachi L8800 amino acid analyzer. Reversed-phase flash column chromatography was performed on BakerbondTM C18, $40 \mu \mathrm{m}$, prep LC packing. HPLC was performed on either a Beckman System Gold or an Agilent 1100 series instrument (diode array detector). For chiral HPLC, a Phenomenex Chirex phase 3126 (D), $(250 \times 4.6 \mathrm{~mm})$ column was utilized. All solvents were HPLC grade, purchased from Fisher Scientific. Amino acid standards were purchased from Aldrich or Fisher Scientific.

\section{Biological Material}

The marine sponge Theonella swinhoei Gray (family Theonellidae) was collected by hand using SCUBA from Milne Bay, Papua New Guinea (S $10^{\circ} 21.55$, E $\left.150^{\circ} 44.70\right)$ in 2001. A voucher specimen of the sample PNG01-5-051 is held at the University of Utah.

\section{Extraction and Isolation}

The frozen sponge ( $400 \mathrm{~g}$ wet $\mathrm{wt})$ was cut into small pieces and soaked in $\mathrm{CH}_{3} \mathrm{CN}-\mathrm{H}_{2} \mathrm{O}(1: 1$ $\mathrm{v} / \mathrm{v}, 3 \times 1000 \mathrm{~mL}$ ). The aqueous $\mathrm{CH}_{3} \mathrm{CN}$ extract was evaporated to dryness under vacuum, and the resulting crude material was applied onto a $\mathrm{C} 18$-column pre-equilibrated with aqueous $\mathrm{CH}_{3} \mathrm{CN}\left(\sim 90 \% \mathrm{H}_{2} \mathrm{O}\right)$. The column was eluted with a step gradient of $\mathrm{CH}_{3} \mathrm{CN}-\mathrm{H}_{2} \mathrm{O}(0-100 \%$ $\mathrm{CH}_{3} \mathrm{CN}$ ) containing $0.05 \%$ TFA. The $20 \% \mathrm{CH}_{3} \mathrm{CN}$ eluate was chromatographed on Diaion HP-20 resin using an aqueous acetone solvent gradient of 20\%-100\% acetone to yield eight fractions. Fractions two through five were combined and further purified on HPLC (Phenomenex Luna $5 \mu \mathrm{m} \mathrm{CN}, 250 \times 10 \mathrm{~mm}$, flow rate $2.5 \mathrm{~mL} / \mathrm{min}$, detection 210 and $230 \mathrm{~nm}$ ) using a gradient of $10 \%-100 \% \mathrm{CH}_{3} \mathrm{CN}$ in $\mathrm{H}_{2} \mathrm{O}(0.05 \%$ TFA) over 30 min to yield four fractions. The third fraction was re-chromatographed, on a C8-HPLC column (ZORBAX Eclipse XDB $5 \mu \mathrm{m}, 150 \times 4.6 \mathrm{~mm}$, flow rate $0.5 \mathrm{~mL} / \mathrm{min}$, detection 210 and $230 \mathrm{~nm}$ ) using a gradient of $50 \%-100 \% \mathrm{MeOH}$ in $\mathrm{H}_{2} \mathrm{O}(0.05 \%$ TFA). Pure theopapuamide (1) was obtained as an off-white amorphous solid $\left(15.8 \mathrm{mg}, 3.95 \times 10^{-3} \%\right.$ yield wet $\left.\mathrm{wt}\right)$.

Theopapuamide (1): off-white amorphous solid, $[\alpha]^{25} \mathrm{D}-3.0(c$ 0.86, MeOH); UV (MeOH) $\lambda_{\max }(\log \varepsilon) 270$ (3.28), $210(4.12) \mathrm{nm}$; IR (film) $v_{\max } 3305,2915,2850,1650,1525,1450$, $1195,1130 \mathrm{~cm}^{-1} ;{ }^{1} \mathrm{H}$ and ${ }^{13} \mathrm{C}$ NMR data, see Table 1; HRESI-FTMS $m / z 1558.90536(\mathrm{M}+$ $\mathrm{H})^{+}$(calculated for $\mathrm{C}_{69} \mathrm{H}_{124} \mathrm{~N}_{17} \mathrm{O}_{23}, 1558.90505$ ).

\section{Base Hydrolysis of Theopapuamide (1)}

Approximately $0.5 \mathrm{mg}$ of $\mathbf{1}$ was treated with $1 \mathrm{~N} \mathrm{KOH}(200 \mu \mathrm{L})$ at $\mathrm{rt}$ for $2 \mathrm{~h}$. The reaction mixture was diluted by adding ice, neutralized with $0.5 \mathrm{~N} \mathrm{HCl}$ and extracted with $n$-BuOH (2 $\times 3 \mathrm{~mL}$ ). The $n-\mathrm{BuOH}$ layer was evaporated to dryness and an aliquot was analyzed by LRESIMS $\left[\mathrm{m} / z .1576 .9(\mathrm{M}+\mathrm{H})^{+}\right]$.

\section{Determination of Absolute Configuration}

(a) Acid Hydrolysis-Theopapuamide (1), $100 \mu \mathrm{g}$, was dissolved in degassed $6 \mathrm{~N} \mathrm{HCl}$ (250 $\mu \mathrm{L})$ and heated in a sealed glass vial at $110^{\circ} \mathrm{C}$ for $12 \mathrm{~h}$. The solvent was removed in vacuo and the residue was analyzed by HPLC. 
(b) Chiral HPLC Analysis-The acid hydrolysate of $\mathbf{1}$ (aliquot of $10 \mu \mathrm{L}$ ) was analyzed by chiral HPLC on a Phenomenex D-penicillamine column [Chirex phase 3126 (D), $(250 \times 4.6$ $\mathrm{mm})]$. The identity of amino acids of the acid hydrolysate were confirmed by comparison of their retention times with those of authentic standards using HPLC under the following conditions: mobile phase, $i \mathrm{PrOH}-2 \mathrm{mM} \mathrm{CuSO}_{4}$ (5:95); flow rate, $1.0 \mathrm{~mL} / \mathrm{min}$; detection, UV $254 \mathrm{~nm}$; retention times of the standards (min): L-NMeGlu (52.3), D-NMeGlu (24.1), L-Asp (20.0), D-Asp (26.9), L-Leu (18.5), D-Leu (29.0), L-NMeLeu (15.0), L-Dpr (5.8), D-Dpr (6.5), D-Orn (3.7), L-Orn (3.5), D/L-allo-Thr (6.3), D-Thr (5.8), L-Thr (5.2); retention times of the component amino acids of the hydrolysate (min): L-NMeGlu (52.4), D-Asp (26.8), L-Leu (18.5), L-NMeLeu (14.9), D-Dpr (6.5), D-Orn (3.7).

(c) HPLC Analysis of Marfey's (L-FDAA) Derivatives-To the peptide hydrolysate (20 $\mu \mathrm{g}$ in $\left.20 \mu \mathrm{L} \mathrm{H}_{2} \mathrm{O}\right)$ was added $6 \%$ triethylamine in $\mathrm{H}_{2} \mathrm{O}(10 \mu \mathrm{L})$ followed by a $1 \%$ solution of 1-fluoro-2,4-dinitrophenyl-5-alanine amide in acetone (L-FDAA, $20 \mu \mathrm{L}$ ). The mixture was heated at $50{ }^{\circ} \mathrm{C}$ in an oil bath for $1 \mathrm{~h}$, quenched with $5 \%$ acetic acid $(10 \mu \mathrm{L})$ and dried in vacuo. The residue was dissolved in $\mathrm{H}_{2} \mathrm{O}(40 \mu \mathrm{L})$ and aliquots $(5-10 \mu \mathrm{L})$ were analyzed by $\mathrm{C} 18$ HPLC. The D- and L-amino acid standards $(1 \mathrm{mg} / \mathrm{mL}, 50 \mu \mathrm{L})$ were derivatized in a similar manner, and the retention times were compared with those of the component amino acids of the peptide hydrolysate. C18-HPLC analysis conditions: column, Phenomenex $\mu \mathrm{m}, 250 \times 4.6$ $\mathrm{mm}$; mobile phase, a gradient of $10 \%-50 \% \mathrm{CH}_{3} \mathrm{CN}$ in $\mathrm{H}_{2} \mathrm{O}(0.05 \%$ TFA) over $30 \mathrm{~min}$; flow rate, $1.0 \mathrm{~mL} / \mathrm{min}$; detection, UV $340 \mathrm{~nm}$; Retention times of authentic L-FDAA-allo- $\mathrm{Thr}(\mathrm{min})$ : L-allo-Thr (19.8) and D-allo-Thr (20.6); retention times of the L-FDAA-allo-Thr of the hydrolysate (min): D-allo-Thr (20.6).

\section{Assay for T cell viability}

CEM-TART cells were maintained in 80\% RPMI medium, $20 \%$ fetal bovine serum supplemented with 100 units $/ \mathrm{mL}$ penicillin, $100 \mu \mathrm{g} / \mathrm{mL}$ streptomycin and $0.25 \mu \mathrm{g} / \mathrm{mL}$ amphotericin $\mathrm{B}$ in a humidified incubator at $37{ }^{\circ} \mathrm{C}, 5 \% \mathrm{CO}_{2} .200 \mu \mathrm{L}$ of cells were seeded in 96-well microtiter plates at a final concentration of 30,000 cells/well. Cells were administered $3.3 \mathrm{ng} / \mathrm{mL}-5 \mu \mathrm{g} / \mathrm{mL}$ (dissolved in DMSO) of compound, each dose in quadruplicate. After 72 hours cells, $11 \mu \mathrm{L}$ MTT $(5 \mathrm{mg} / \mathrm{mL})$ was added to each well, and plates were incubated for an additional 4 hours. The medium was aspirated, $100 \mu \mathrm{L}$ of DMSO added to the cells to solubilize purple formazan product and the absorbance read at $570 \mathrm{~nm}$ using a plate reader (Bio-Rad). Average absorbance for each set of compound-treated wells was compared to the average absorbance of the control wells to determine the fractional survival at any particular drug concentration. The effective concentration $50\left(\mathrm{EC}_{50}\right)$ is defined as the drug concentration that yielded a fractional survival of $50 \%$. $\mathrm{EC}_{50}$ values reported are the average of three independentexperiments and were determined using GraphPad Prism. The following reagent was obtained through the AIDS Research and Reference Reagent Program, Division of AIDS, NIAID, NIH: CEM-TART from Drs. Herbert Chen, Terence Boyle, Michael Malim, Bryan Cullen, and H. Kim Lyerly.

\section{Cell culture and MTT assay. 16}

The cancer cell line HCT-116 (human colon tumor) was grown at $37^{\circ} \mathrm{C}, 5 \% \mathrm{CO}_{2}$ in $\mathrm{McCoy}$ 's 5a medium containing $10 \%$ fetal bovine serum, penicillin $(50 \mathrm{IU} / \mathrm{mL})$, streptomycin $(50 \mu \mathrm{g} /$ $\mathrm{mL}$ ) and $2 \mathrm{mM} \mathrm{L}$-glutamine. Cells were plated at a density of 5000 cells/well in a $96-$ well plate. Twenty-four hours after plating, they were exposed to medium containing compound at a concentration of $0.1 \mu \mathrm{M}$ to $100 \mu \mathrm{M}$ for $48 \mathrm{~h}$ at $37^{\circ} \mathrm{C}$. After exposure of cells to compounds, $100 \mu \mathrm{L}$ of fresh culture medium containing MTT at a final concentration of $0.3 \mathrm{mg} / \mathrm{mL}$ was added to each well and incubated for $3 \mathrm{~h}$ at $37^{\circ} \mathrm{C}$. Formazan crystals were solubilized in 100 $\mu \mathrm{L}$ of DMSO. The absorbance of each well was measured by a microplate reader (Multi-skan 
labsystems) at $570 \mathrm{~nm}$. The percentage cytotoxicity was calculated by comparison of the $A_{570}$ reading from treated versus control cells.

\section{Supplementary Material}

Refer to Web version on PubMed Central for supplementary material.

\section{Acknowledgements}

The authors wish to acknowledge the government of Papua New Guinea and PNG BioNET for permits to collect the sponge. We thank P. Krishna, University of Utah Mass Spectrometry and Proteomics Core Facility, for performing the LRESIMS experiments. The following NIH and NSF grants funded NMR instrumentation, RR06262, RR13030, DBI-0002806. This project was funded by NIH grant CA 36622.

\section{References}

1. (a) Bewley CA, Faulkner DJ. Angew Chem Int Ed 1998;37:2162-2178. (b) Fusetani N, Matsunaga S. Chem Rev 1993;93:1793-1806.

2. Zampella A, D’Auria MV, Paloma LG, Casapullo A, Minale L, Debitus C, Henin Y. J Am Chem Soc 1996;118:6202-6209.

3. Oku N, Gustafson KR, Cartner LK, Wilson JA, Shigematsu N, Hess S, Pannell LK, Boyd MR, McMahon JB. J Nat Prod 2004;67:1407-1411. [PubMed: 15332865]

4. Ford PW, Gustafson KR, McKee TC, Shigematsu N, Maurizi LK, Pannell LK, Williams de Silva ED, Lassota P, Allen TM, Soest RV, Andersen RJ, Boyd MR. J Am Chem Soc 1999;121:5899-5909.

5. (a) Okamoto N, Hara O, Makino K, Hamada Y. Tetrahedron Assym 2001;12:1353-1358. (b) Liang B, Carroll J, Joullié MM. Org Lett 2000;2:4157-4160. [PubMed: 11150188] (c) Acevedo CM, Kogut EF, Lipton MA. Tetrahedron 2001;57:6353-6359. [PubMed: 18159221] (d) Çalimsiz S, Lipton MA. J Org Chem 2005;70:6218-6221. [PubMed: 16050680] (e) Thoen JC, Ramos M, Lipton MA. Org Lett 2002;4:4455-4458. [PubMed: 12465911] (f) Zampella A, D’Orsi R, Sepe V, Casapullo A, Monti MC, D’Auria MV. Org Lett 2005;7:3585-3588. [PubMed: 16048348] (g) Okamoto N, Hara O, Makino K, Hamada Y. J Org Chem 2002;67:9210-9215. [PubMed: 12492322]

6. Ratnayake AS, Davis RA, Harper MK, Veltri CA, Andjelic CD, Barrows LR, Ireland CM. J Nat Prod 2005;68:104-107. [PubMed: 15679329]

7. (a) Köck M, Kessler H, Seebach D, Thaler A. J Am Chem Soc 1992;114:2676-2686. (b) Kessler H, Hehlein W, Schuck R. J Am Chem Soc 1982;104:4534-4540.

8. 2D $\left[{ }^{1} \mathrm{H},{ }^{1} \mathrm{H}\right]$ TOCSY using a z-DIPSI-2 isotropic mixing scheme. Cavanagh J, Rance M. J Magn Reson 1992;96:670-678.

9. Standard amino acid analysis, $5.7 \mathrm{~N} \mathrm{HCl}, 110^{\circ} \mathrm{C}, 16 \mathrm{~h}$; concentrations of the amino acids were quantified using a Hitachi model L8800 analyzer.

10. 2D $\left[{ }^{1} \mathrm{H},{ }^{1} \mathrm{H}\right]$ NOESY with watergate water suppression. Piotto M, Saudek V, Sklenáà V. J Biomol NMR 1992;2:661-665. [PubMed: 1490109]

11. (a) Bodo B, Hebrard P, Molho L, Molho D. Tetrahedron Lett 1973;18:1631-1634. (b) White JD, Johnson AT. J Org Chem 1994;59:3347-3358.

12. (a) Edman P. Acta Chem Scand 1950;4:283-293. Yarwood, A. Chapter 6. In: Findlay, JBC.; Geisow, MJ., editors. Protein Sequencing, a practical approach. IRL Press; Oxford: 1989. p. 119-145.

13. Trypsin digestion, $37^{\circ} \mathrm{C}$, $\mathrm{pH} 7.9,2$ days; Thermolysin digestion, $37^{\circ} \mathrm{C}$, pH 8.1, 1-2 days; Pepsin digestion, $37^{\circ} \mathrm{C}, \mathrm{pH} 1.5,2$ days.

14. (a) McDonald LA, Barbieri LR, Carter GT, Kruppa G, Feng X, Lotvin JA, Siegel MM. Anal Chem 2003;75:2730-2739. [PubMed: 12948143] (b) Palmblad M, Håkansson K, Håkansson P, Feng X, Cooper HJ, Giannakopulos AE, Green PS, Derrick PJ. Eur J Mass Spectrom 2000;6:267-275.

15. (a) Bhushan R, Brückner H. Amino Acids 2004;27:231-247. [PubMed: 15503232] (b) B'Hymer C, Bayon MM, Caruso JA. J Sep Sci 2003;26:7-19. (c) Hess S, Gustafson KR, Milanowski DJ, Alvira E, Lipton MA, Pannell LK. J Chromatogr A 2004;1035:211-219. [PubMed: 15124814] 
16. Mosmann T. Rapid colorimetric assay for cellular growth and survival: application to proliferation and cytotoxicity assays. J Immunol Methods 1983;65:55-63. [PubMed: 6606682] 


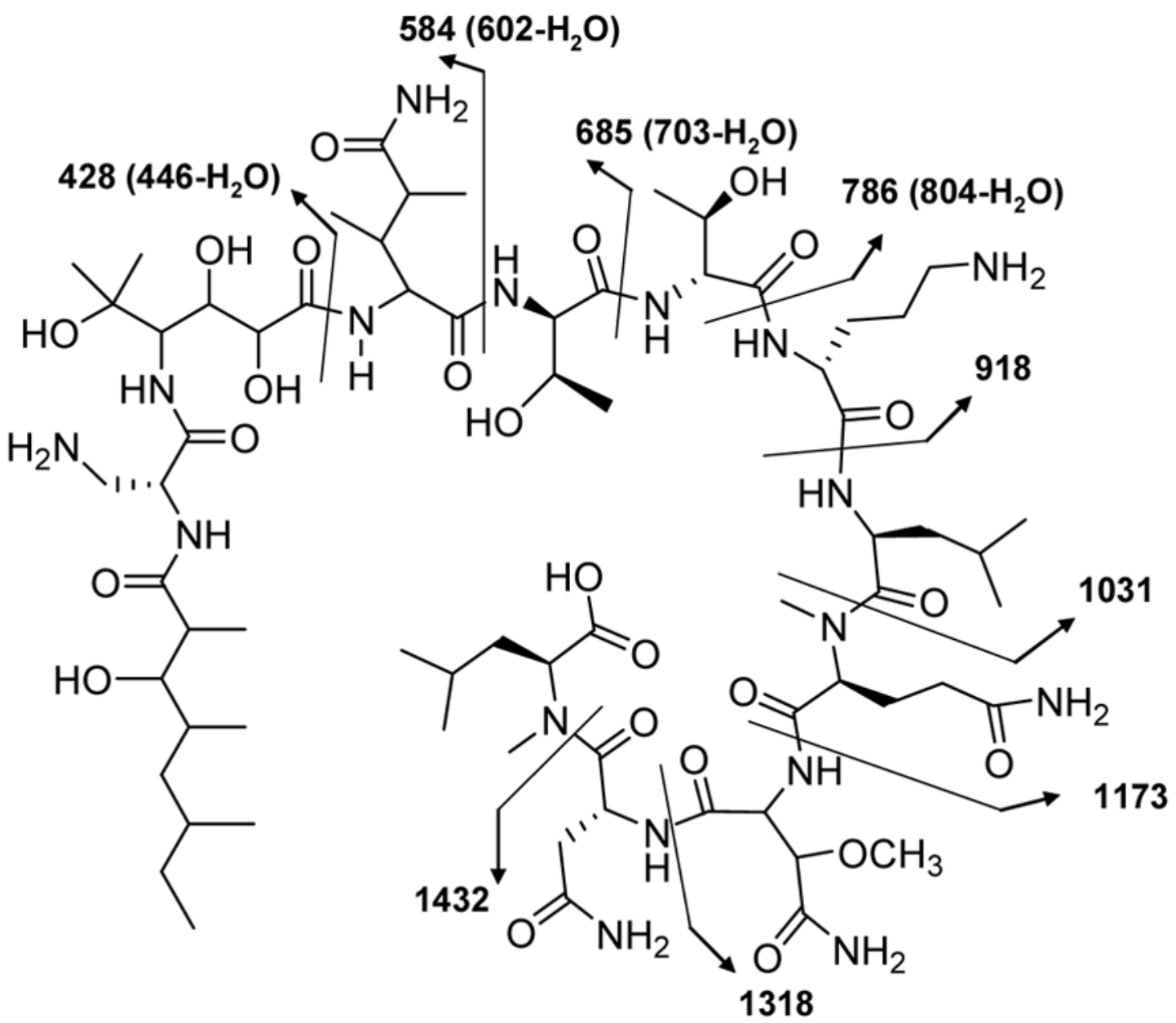

Figure 1.

SORI-CID MS/MS fragmentations of the acyclic peptide (2) 


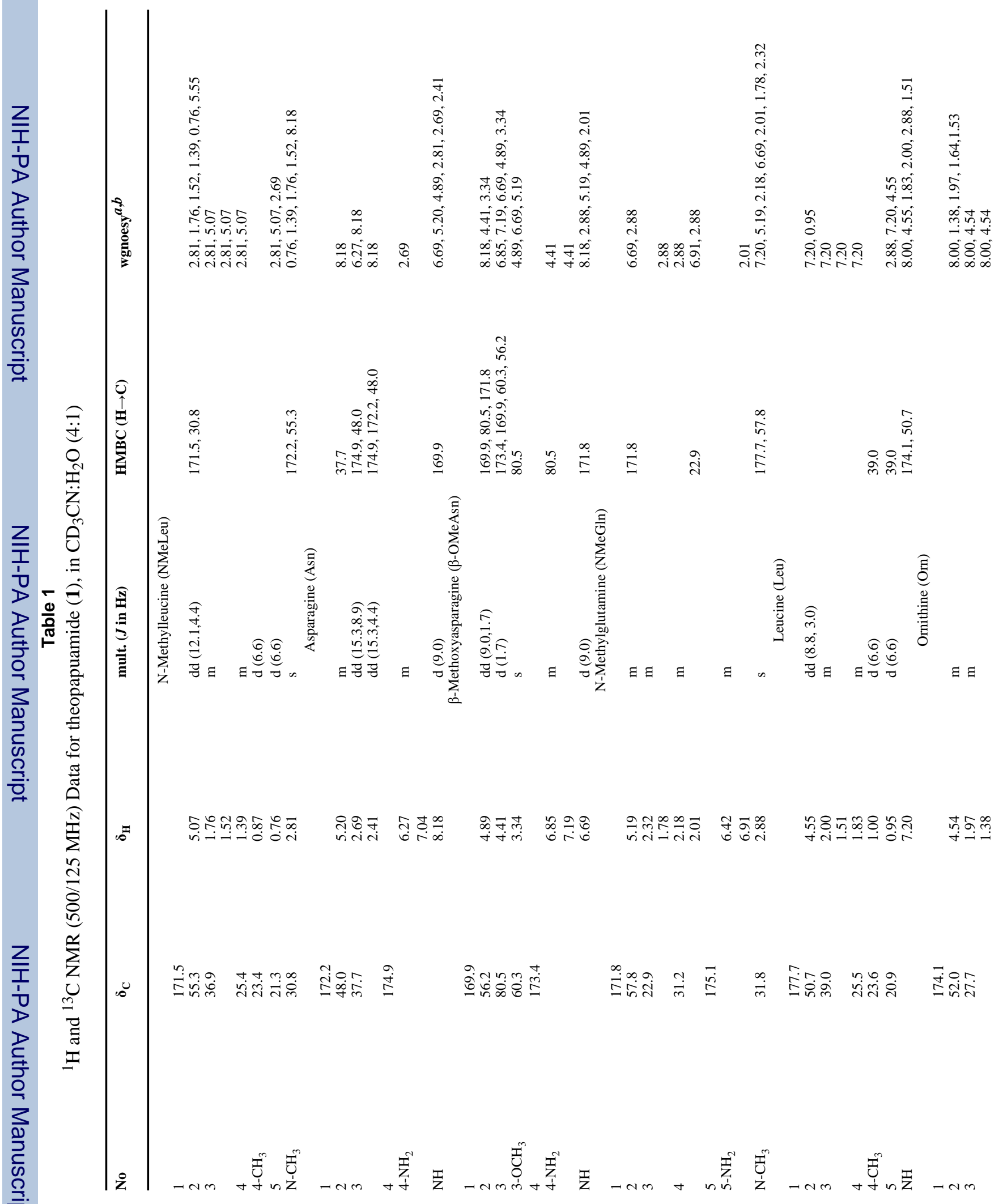




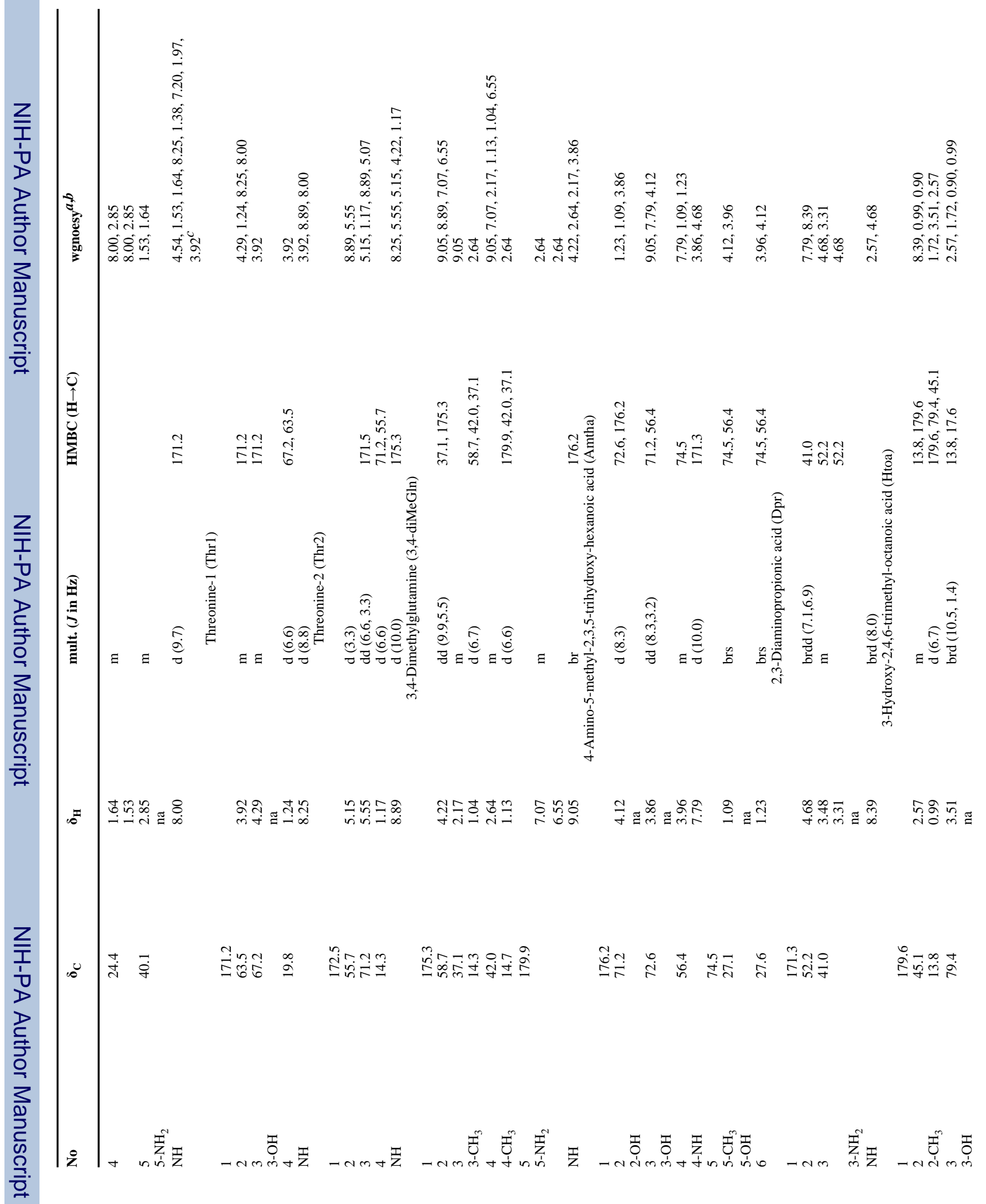




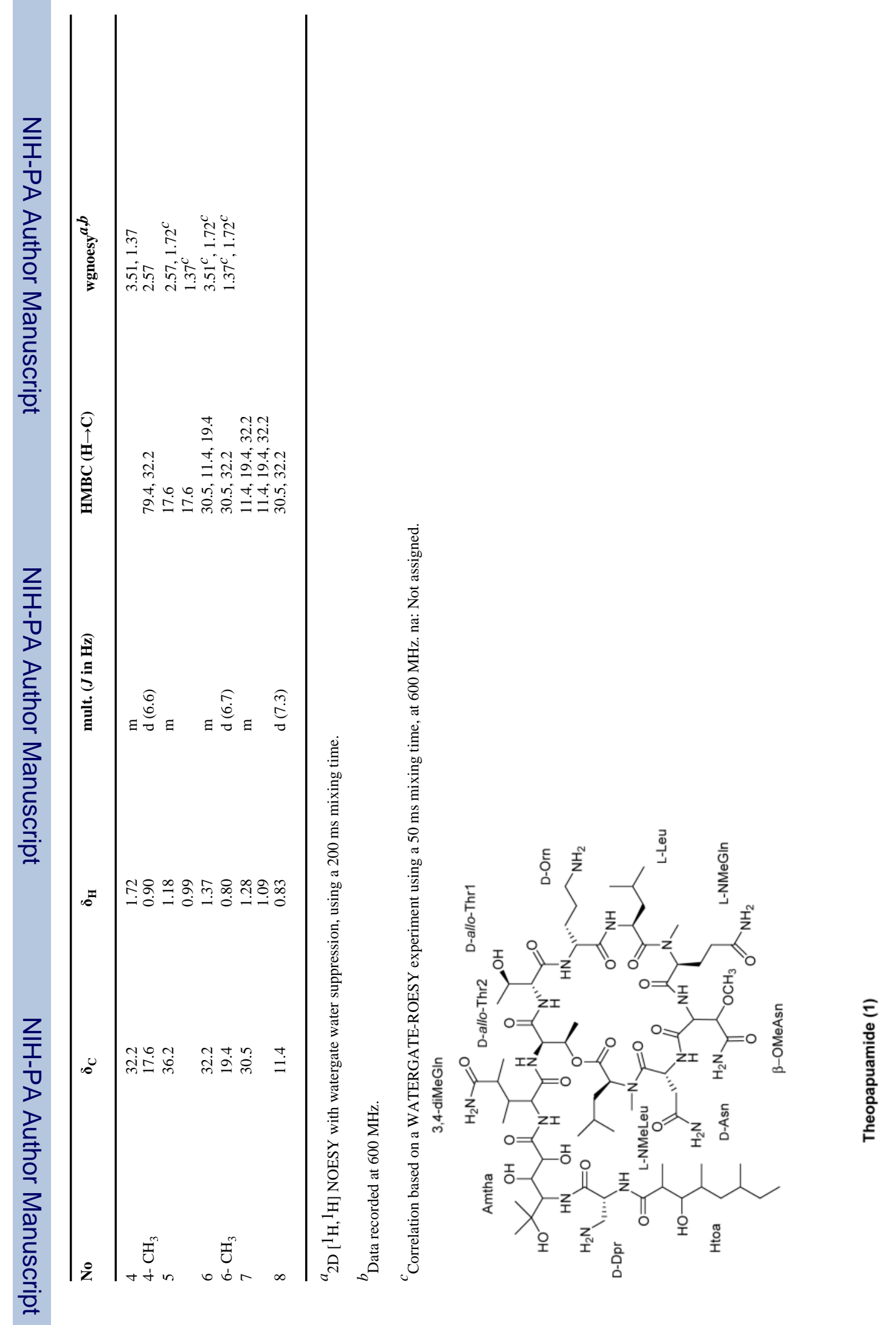

